\title{
Evaluation of Advanced Varietal Rice Genotypes for Leaf Blast Reaction, Genotypic Performance and Correlation Studies
}

\author{
G.N. Hosagoudar* and Basavaraj S. Kovi \\ Agricultural and Horticultural Research Station, Ponnampet, UAHS, Shivamogga \\ (Karnataka) - 571216, India \\ *Corresponding author
}

\section{Keywords}

Rice Blast, Genetic advance,

Heritability and Correlation

Article Info

Accepted:

04 March 2018

Available Online:

10 April 2018

\section{A B S T R A C T}

The present study was carried out at Agricultural and Horticultural Research Station, Ponnampet, University of Agricultural and Horticultural Sciences, Shivamogga during 2015. The experimental material comprised of 15 advanced varietal lines including existing variety as check. Mean performance of individual rice genotypes revealed that the days to $50 \%$ flowering found to vary from 85.00 days to 114.50 . Plant height was found to vary from $59.84 \mathrm{~cm}$ to $91.33 \mathrm{~cm}$ with average height of $75.42 \mathrm{~cm}$. Number of panicles per $\mathrm{m}^{2}$ area ranged from 304.52 (IET-1912) to 580.80 (IET-1902) with mean of 432.21 panicles $/ \mathrm{m}^{2}$ area. The genotype IET-1912 produced maximum grain yield $(5172.60 \mathrm{~kg} / \mathrm{ha})$ and found to be $20.77 \%$ superior in grain yield than local check Tunga $(3096.09 \mathrm{~kg} / \mathrm{ha})$ followed by IET-1914 (5059.61 kg/ha) which found 19.64\% superior, whereas IET-1908 was found to be $3.74 \%$ inferior in grain yield $(2722.42 \mathrm{~kg} / \mathrm{ha})$ than local check. Analysis of variance revealed highly significant sum of squares due to genotypes for all the characters indicating existence of ample variability among the genotypes. The traits such as plant height, number of panicles $/ \mathrm{m}^{2}$ and grain yield which showed high heritability coupled with high genetic advance could be used as selection criteria for their improvement since these are governed by additive gene action. The traits like plant height and days to 50\% flowering could be used as indirect selection criteria for their simultaneous improvement.

\section{Introduction}

Rice (Oryza sativa L.) $(2 \mathrm{n}=24)$ is the world's most important cereal crop and serves as the primary source of staple food for lives of billions of people around the World. The crop belongs to the family Poaceae and sub-family Oryzoidea and it is one of the very few crop species endowed with rich genetic diversity which accounts for more than 100,000 landraces and improved cultivars. The crop has undoubtedly evolved very high levels of adaptation to various ecological habitats ranging from low land rain-fed situation to upland irrigated situation. Globally rice was grown on 159.19 mha area during 2015-16 producing $472.25 \mathrm{mt}$ with average productivity of $4.42 \mathrm{t} / \mathrm{ha}$, while in India 104.41 $\mathrm{mt}$ rice production was recorded from 43.5 mha area with the productivity of $3.6 \mathrm{q} / \mathrm{ha}$ (Anon, 2017). Although India has maximum acreage under cultivation among the rice growing countries, it lags behind with respect to productivity level. Low rice productivity is 
attributed to the lack of high yielding varieties, various biotic and abiotic stresses and several other constraints. Among various biotic stresses, leaf blast caused by Pyricularia oryzae is one of the major diseases of rice causing substantial yield losses.

The progress in breeding for yield and its contributing characters of any crop is polygenically controlled, environmentally influenced and determined by the magnitude and nature of their genetic variability (Wright, 1935 and Fisher, 1981). Genetic variability and character association are pre-requisites for improvement of any crop including rice for selection of superior genotypes and improvement of any trait (Krishnaveni et al., 2006). It is very difficult to judge whether observed variability is highly heritable or not. Moreover, knowledge of heritability is essential for selection based improvement as it indicates the extent of transmissibility of a character into its off springs. Knowledge of correlation between yield and its contributing characters are basic and foremost endeavor to find out guidelines for plant selection. Keeping in view the above facts, the present investigation was undertaken to study the behavior of resistance against Pyricularia oryzae and to know the variability and correlation among yield and its contributing characters in 15 rice genotypes under rain fed hilly ecosystem.

\section{Materials and Methods}

The experiment comprised of 15 advanced varietal lines and existing varieties of rice grown during kharif 2015 at Agricultural and Horticultural Research Station, Ponnampet, University of Agricultural and Horticultural Sciences, Shivamogga. These fifteen genotypes were evaluated in randomized complete block design with two replications. Seedlings were raised by adopting Uniform Blast Nursery (UBN) pattern for evaluation of leaf blast disease reaction at seedling stage and later 25-30 days old seedlings were transplanted in a plot of $6.43 \mathrm{~m}^{2}$ for each genotype at a spacing of $15 \times 15 \mathrm{~cm}$ between and within rows. All the recommended package of practices was followed to raise a good crop. The observations were recorded on five randomly selected plants from each plot for scoring against blast disease and plant height while days to $50 \%$ flowering, number of panicles $/ \mathrm{m}^{2}$ area and grain yield/ha were recorded on net plot basis.

The AHRS, Ponnampet is considered as one of the internationally recognised hotspot for leaf blast disease hence genotypes were firstly evaluated for disease reaction under field condition and the genotypes were scored based on leaf blast severity following SES scale of IRRI (1996). The variability was estimated as per procedure for analysis of variance suggested by Panse and Sukhatme (1985), GCV and PCV by Burton and De Vane (1952) and heritability and genetic advance by Johnson et al., (1955). Correlation coefficient was worked as per Al-Jibouri et al., (1958).

\section{Results and Discussion}

Results of table 1 indicate disease reaction of various genotypes and their mean performance for various characters. Results on field screening of genotypes for leaf blast reaction revealed that out of fifteen entries 8 entries showed resistant reaction and remaining 7 entries exhibited moderately resistant reaction.

The mean performance of individual rice genotypes revealed that the days to $50 \%$ flowering found to vary from 85.00 days to 114.50 days with average of 102.20 days. Genotypes with shorter days to $50 \%$ flowering are considered as early genotypes and are considered as desirable; therefore, early genotype IET-1910 (85.00) is preferred over 
long duration genotype IET-1902 (114.50). Plant height was found to vary from $59.84 \mathrm{~cm}$ to $91.33 \mathrm{~cm}$ with average height of $75.42 \mathrm{~cm}$. Number of panicles $/ \mathrm{m}^{2}$ area ranged from 304.52 (IET-1912) to 580.80 (IET-1902) with mean of 432.21 panicles $/ \mathrm{m}^{2}$ area. Based on the mean performance of rice genotypes for yield the genotypes in present study differed significantly. IET-1912 produced maximum grain yield (5172.60 kg/ha) and found to be $20.77 \%$ superior in grain yield than local check Tunga (3096.09 kg/ha) followed by IET-1914 (5059.61 kg/ha) which found $19.64 \%$ superior, whereas IET-1908 was found to be $3.74 \%$ inferior in grain yield than local check (2722.42 kg/ha) the overall average grain yield was $3775.74 \mathrm{~kg} / \mathrm{ha}$. Similar findings on mean performance of rice genotypes for various traits were also reported by Hammound (2005), Sedeek et al., (2009) and Anis et al., (2016).

The analysis of variance (Table 2) revealed that sum of squares due to treatment were highly significant for all the characters under study which indicated enough variability existed among the genotypes. The observed differences among the genotypes may be attributed to their different geographical origin. Similar reports on phenotypic variation among rice genotypes were observed by Elayaraja et al., (2005) and Pandey et al., (2009).

The estimation of genetic parameters indicated that phenotypic variance was higher than genotypic variance for all the traits which revealed considerable effect of environment on the expression of these traits. Consequently phenotypic coefficient of variation (PCV) was higher than genotypic coefficient of variation (GCV) for all the characters. The estimates of PCV was highest for grain yield (22.49\%) whereas low to moderate PCV were recorded for Days to $50 \%$ flowering $(8.19 \%)$, plant height $(11.88 \%)$ and number of panicles $/ \mathrm{m}^{2}$ area $(18.77 \%)$. Similarly, low to moderate GCV values were recorded for all the characters namely days to $50 \%$ flowering $(8.03 \%)$, plant height $(11.84 \%)$, number of panicles $/ \mathrm{m}^{2}$ area $(18.27 \%)$ and grain yield (18.00). Similar findings on analysis of variance and genetic variability parameters were reported in 47 rice genotypes by Jayasudha and Sharma (2010).

The large difference between PCV and GCV values observed for grain yield indicated large effect of environment on the expression of these traits. On the contrary, days to $50 \%$ flowering, plant height and panicle number $/ \mathrm{m}^{2}$ area are least affected by environment as indicated by less difference between PCV and GCV values. Ramanjaneyulu et al., (2014) also reported similar results of more difference between PCV and GCV for yield.

The estimates of PCV and GCV clearly indicate the presence of degree of genetic variation; however, it is the estimates of heritability and genetic advance which determine the amount of heritable portion of variation. According to Lush (1949), heritability (broad sense) is the ratio of genotypic variance to phenotypic variance, expressed in percentage. The estimates of heritability are more advantageous when expressed in terms of genetic advance.

Heritability is classified as high (above 60\%), medium (30\%-60\%) and low (below 30\%). High heritability estimates were exhibited for all the character under study (Table 3 ). The estimates of heritability (broad sense) ranged from 64.05 percent to 99.20 percent. Plant height $(99.20 \%)$ showed highest heritability followed by days to $50 \%$ flowering $(95.96 \%)$, panicle number $/ \mathrm{m}^{2}$ area $(94.77 \%)$ and grain yield $(64.05 \%)$. Similar findings of high heritability values were reported for grain yield by Panwar (2005), Kumar et al., (2007) and Chaurasia et al., (2012). 
Table.1 Disease reaction and mean performance of various genotypes under study

\begin{tabular}{|c|c|c|c|c|c|c|c|}
\hline \multirow{2}{*}{$\begin{array}{l}\text { SI. } \\
\text { No. }\end{array}$} & \multirow{2}{*}{$\begin{array}{c}\text { Designation } \\
\text { IET No. }\end{array}$} & \multirow{2}{*}{$\begin{array}{l}\text { Disease } \\
\text { Reaction } \\
\text { (SES 0-9 } \\
\text { Scale) } \\
\text { Leaf Blast }\end{array}$} & \multicolumn{2}{|c|}{ Growth Parameters } & \multicolumn{2}{|c|}{ Yield Parameters } & \multirow{2}{*}{$\begin{array}{c}\text { Percent } \\
\text { increase } \\
\text { over local } \\
\text { check }\end{array}$} \\
\hline & & & $\begin{array}{l}\text { Days to } \\
50 \% \\
\text { Flowering }\end{array}$ & $\begin{array}{l}\text { Plant } \\
\text { height } \\
(\mathrm{cm})\end{array}$ & $\begin{array}{c}\text { No. of } \\
\text { Panicles } / \mathrm{m}^{2}\end{array}$ & $\begin{array}{c}\text { Grain } \\
\text { yield } \\
\mathrm{Kg} / \mathrm{ha}\end{array}$ & \\
\hline 1 & 1901 & 2 & 105.00 & 59.84 & 544.50 & 4473.31 & 13.77 \\
\hline 2 & 1902 & 2 & 114.50 & 64.00 & 580.80 & 3391.46 & 2.95 \\
\hline 3 & 1903 & 1 & 98.00 & 68.17 & 500.94 & 4081.85 & 9.86 \\
\hline 4 & 1904 & 2 & 109.50 & 74.00 & 370.26 & 2836.30 & -2.60 \\
\hline 5 & 1905 & 2 & 100.50 & 79.00 & 392.04 & 3167.26 & 0.71 \\
\hline 6 & 1906 & 3 & 109.00 & 77.00 & 413.82 & 3137.01 & 0.41 \\
\hline 7 & 1907 & 1 & 109.00 & 74.00 & 341.22 & 3902.14 & 8.06 \\
\hline 8 & 1908 & 1 & 106.00 & 71.33 & 508.20 & 2722.42 & -3.74 \\
\hline 9 & 1909 & 1 & 100.50 & 82.00 & 406.56 & 3843.42 & 7.47 \\
\hline 10 & 1910 & 2 & 85.00 & 76.67 & 406.56 & 3649.47 & 5.53 \\
\hline 11 & 1911 & 2 & 97.00 & 76.83 & 421.08 & 3535.59 & 4.39 \\
\hline 12 & 1912 & 1 & 94.00 & 91.33 & 304.92 & 5172.60 & 20.77 \\
\hline 13 & 1913 & 1 & 95.50 & 65.33 & 508.20 & 4567.62 & 14.72 \\
\hline 14 & 1914 & 1 & 95.50 & 81.66 & 348.48 & 5059.61 & 19.64 \\
\hline 15 & $\begin{array}{l}\text { 1915/Tunga } \\
\text { (LC) }\end{array}$ & 1 & 114.00 & 90.16 & 435.60 & 3096.09 & 0.00 \\
\hline & \multicolumn{2}{|c|}{ Mean } & 102.20 & 75.42 & 432.21 & $3,775.74$ & \\
\hline & \multicolumn{2}{|c|}{ CV (\%) } & 1.65 & 1.65 & 1.07 & 4.29 & \\
\hline & \multicolumn{2}{|c|}{$\mathrm{CD}(0.05)$} & 3.61 & 3.61 & 1.72 & 39.80 & \\
\hline
\end{tabular}

Table.2 Analysis of variance for different characters under study

\begin{tabular}{|c|c|c|c|c|c|}
\hline & df & $\begin{array}{l}\text { Days to } 50 \% \\
\text { Flowering }\end{array}$ & $\begin{array}{l}\text { Plant height } \\
\text { (cm) }\end{array}$ & $\begin{array}{c}\text { No. of } \\
\text { Panicles } / \mathrm{m}^{2}\end{array}$ & $\begin{array}{l}\text { Grain yield } \\
\text { Kg/ha }\end{array}$ \\
\hline Source & & \multicolumn{4}{|c|}{ Mean sum of squares } \\
\hline Replication & 1 & 3.333 & 2.511 & $2,031.00$ & $472,985.02$ \\
\hline Treatment & 49 & $137.414 * *$ & $160.035 * *$ & $12,813.47 * *$ & $1,182,991.12 * *$ \\
\hline Error & 49 & 2.833 & 0.645 & 344.36 & $259,265.22$ \\
\hline $\mathbf{S E} \pm \mathbf{M}$ & & 1.19 & 0.57 & 13.12 & 360.05 \\
\hline
\end{tabular}

*, ** indicates significant at $5 \%$ and $1 \%$ level, respectively. 
Table.3 Estimates of genetic parameters for different characters in rice genotypes

\begin{tabular}{|l|c|c|c|c|}
\hline Genetic parameter & $\begin{array}{c}\text { Days to 50\% } \\
\text { Flowering }\end{array}$ & $\begin{array}{c}\text { Plant height } \\
(\mathbf{c m})\end{array}$ & $\begin{array}{c}\text { No. of } \\
\text { Panicles/m }\end{array}$ & $\begin{array}{c}\text { Grain yield } \\
\text { Kg/ha }\end{array}$ \\
\hline Mean & 102.20 & 75.42 & 432.21 & $3,775.74$ \\
\hline$\sigma^{2} \mathbf{p}$ & 70.12 & 80.35 & 6578.91 & 721128.08 \\
\hline$\sigma^{2} \mathrm{~g}$ & 67.29 & 79.70 & 6234.56 & 461862.91 \\
\hline PCV $(\%)$ & 8.194 & 11.884 & 18.766 & 22.491 \\
\hline GCV $(\%)$ & 8.026 & 11.836 & 18.269 & 17.999 \\
\hline $\mathrm{h}^{2}$ bs & 95.96 & 99.197 & 94.766 & 64.047 \\
\hline GAM & 16.197 & 24.285 & 36.635 & 29.674 \\
\hline
\end{tabular}

Where $\sigma^{2} p=$ phenotypic variance, $\sigma^{2} g=$ genotypic variance, PCV $=$ phenotypic coefficient of variation, GCV = genotypic coefficient of variation, $h^{2} b s=$ heritability in broad sense, $G A M=$ genetic advance as per cent of mean

Table.4 Genotypic and phenotypic correlations matrix

\begin{tabular}{|l|l|l|l|l|}
\hline & $\begin{array}{l}\text { Days to 50\% } \\
\text { Flowering }\end{array}$ & $\begin{array}{l}\text { Plant } \\
\text { Height }\end{array}$ & Panicles/m & $\begin{array}{l}\text { Grain } \\
\text { Yield/Ha }\end{array}$ \\
\hline Days to 50\% Flowering & 1.000 & $-0.150^{\mathrm{NS}}$ & $0.283^{\mathrm{NS}}$ & $-0.511^{* *}$ \\
\hline Plant Height & $-0.149^{\mathrm{NS}}$ & 1.000 & $-0.758^{* *}$ & $0.058^{\mathrm{NS}}$ \\
\hline Panicles/M2 & $0.297^{\mathrm{NS}}$ & $-0.777^{* *}$ & 1.000 & $-0.174^{\mathrm{NS}}$ \\
\hline Grain Yield/Ha & $-0.564^{* *}$ & $0.062^{\mathrm{NS}}$ & $-0.252^{\mathrm{NS}}$ & 1.000 \\
\hline
\end{tabular}

Upper diagonal values are phenotypic correlation values and lower diagonal values are genotypic correlation values

High heritability values of a trait indicate less effect of environment on their expression.

The plant breeder, therefore adopt simple selection method on the basis of the phenotype of the characters which ultimately improves the genetic background of these traits.

The estimates of genetic advance as per cent of mean provide more reliable information regarding the effectiveness of selection in improving the traits. Genetic advance denotes the improvement in the mean performance of the selected individuals over the base population.

Perusal of table 3 revealed moderate to low estimates of genetic advance for the traits under study. The genetic advance as per cent of mean was found to be highest for panicle number $/ \mathrm{m}^{2}$ area $(36.63 \%)$, grain yield $(29.67 \%)$ followed by plant height $(24.28 \%)$ while moderate value was recorded for days to $50 \%$ flowering
(16.20\%). Since the broad sense heritability includes both additive and non-additive components of genetic variance, heritability alone will not be of much practical value hence the concurrent use of genetic advance along with heritability would be more useful in predicting the resultant effect of selection on phenotypic expression (Johnson et al., 1955). In the present study, high heritability coupled with high genetic advance as percent of mean was observed for plant height, number of panicles $/ \mathrm{m}^{2}$ area and grain yield while high heritability coupled with moderate genetic advance as percent of mean was observed for days to $50 \%$ flowering. These findings are in accordance with the results of Dhanwani et al., (2013) who found the higher magnitude of PCV and GCV for number of grains per panicle $(23.85 \% ; 23.10 \%)$ and grain yield $(23.17 \%$; $22.04 \%)$.

The additive gene action is involved in the expression of those characters which show high 
heritability coupled with high genetic advance (Panse, 1957) thus can be improved through simple or progeny selection methods while the characters with high heritability coupled with moderate or low genetic advance can be improved by inter-mating superior individuals from segregating population of a cross (Samadhia, 2005).

Correlation studies (Table 4) revealed that plant height had significantly negative correlation with number of panicle $/ \mathrm{m}^{2}$ area at both genotypic level (-0.777) and phenotypic level (0.758 ) this indicated shorter plants produced more panicles. Days to $50 \%$ flowering exhibited significantly negative correlation with yield at both genotypic level (-0.564) and phenotypic level (-0.511) this indicated shorter duration genotypes produced higher grain yields. Kalyan et al., (2017) reported similar results of negative correlation between days to $50 \%$ flowering and yield but he reported contrary results to the present results for correlation between plant height and tiller number.

From the present investigation it has been concluded that eight genotypes including local check were found to be resistant to leaf blast disease while seven entries showed moderately resistant reaction to leaf blast disease. The mean performance of individual rice genotypes revealed that the days to $50 \%$ flowering found to vary from 85.00 days to 114.50 . Plant height was found to vary from $59.84 \mathrm{~cm}$ to $91.33 \mathrm{~cm}$ with average height of $75.42 \mathrm{~cm}$. Number of panicles per $\mathrm{m}^{2}$ area ranged from 304.52 (IET1912) to 580.80 (IET-1902) with mean of 432.21 panicles $/ \mathrm{m}^{2}$ area. The genotype IET1912 produced maximum grain yield $(5172.60$ $\mathrm{kg} / \mathrm{ha}$ ) and found to be $20.77 \%$ superior in grain yield than local check Tunga (3096.09 kg/ha) followed by IET-1914 (5059.61 kg/ha) which found $19.64 \%$ superior, whereas IET-1908 was found to be $3.74 \%$ inferior in grain yield $(2722.42 \mathrm{~kg} / \mathrm{ha})$ than local check. Analysis of variance revealed highly significant sum of squares due to genotypes for all the characters indicating existence of ample variability among the genotypes. The traits such as plant height, number of panicles $/ \mathrm{m}^{2}$ and grain yield which showed high heritability coupled with high genetic advance could be used as selection criteria for their improvement since these are governed by additive gene action. The traits like plant height and days to $50 \%$ flowering could be used as indirect selection criteria for their simultaneous improvement.

\section{References}

Al-Jibouri, H. A., Miller, P. A. and Robinson, H. F., 1958. Genotypic and environmental variances and covariances in upland cotton cross of interspecific origin. Agron. J., 50: 533-535.

Anis, G., Sabagh, A. E. L., Ghareb, A. and ELRewainy, I., 2016, Evaluation of promising lines in rice (Oryza sativa L.) to agronomic and genetic performance under Egyptian conditions. Intern. J. Agron. and Agri. Res.8 (3): 52-57.

Anonymous, 2017, World Agricultural Production.

Burton, F. W. and Devane E. H. (1952). Estimating heritability in tall fescues (Tevisia araundica) from replicated clonal natural materials. Agronomy Journal, 45: 171-181.

Chaurasia, A. K., Rai, P. K. and Kumar, A., 2012, Estimation of genetic variability, heritability and genetic advance in aromatic fine grain rice. Romanian $J$. of Biol.-Pl. Bio. (Bucharest) 57: 71-76.

Dhanwani, R. K., Sarawgi, A. K., Solanki, A. and Tiwari, J. K., 2013, Genetic variability analysis for various yield attributing and quality traits in rice $(O$. Sativa L.). The Bioscan, 8(4): 1403-1407.

Elayaraja, K., Prakash, M., Saravana, K., Kuma, B. S. and Ganesan, J., 2005, Studies on variability, heritability and genetic advance for quantitative characters in rice (Oryza sativa L.). Crop. Res. 29: 134137.

Fisher, R. A., 1981. The correlation among relative on the supposition of Mendelian 
Inheritance. Trans. Royal Soc. Edinberg. 52: 314-318.

Hammoud, S. A., 2005, Genetic behavior of some agronomic characters in two rice crosses. Egypt. J. Agric. Res. 83(5): 305322.

IRRI, 1996, Standard evaluation system for rice. International Rice Testing Program. Philippines.

Jayasudha, S. and Sharma, D., 2010, Genetic parameters of variability, correlation and path co-efficient for grain yield and physiological traits in rice (Oryza sativa L.) under shallow low land situation. Electronic J. of Pl. Breeding. 1(5): 33-38.

Johnson, H. W., Robinson, H. F. and Comstock, R. E., 1955, Genotypic and phenotypic correlations in soybean and their implications in selections. Agron. J.47: 477-483.

Kalyan, B., Radha Krishna, K. V. and Subba Rao, L. V., 2017, Correlation Coefficient Analysis for Yield and its Components in Rice (Oryza sativa L.) Genotypes. Int. J. Curr. Microbiol. App. Sci. 6(7): 24252430.

Krishnaveni, B., Shobharani, N. and Ramprasad, A. S., 2006. Genetic parameters for quality characteristics in aromatic rice. Oryza 43(3): 234-237.

Kumar, S. T., Narasimman, R., Eswaran, R., Kumar, C. P. S. and Anandan, A., 2007, Studies on genetic variability, heritability and genetic advance in segregating generations of rice (Oryza sativa L.). Int. J. of Pl. Scie., 2: 48-51.

Lush, J. L., 1949, Inter-se, correlation and regression of characters. Proceeding of American
Panse, V. G. and Sukhatme, P. V., 1985, Statistical Methods for Agricultural Workers, Indian Council of Agricultural Research, New Delhi.

Panse, V.G. 1957. Genetics of quantitative characters in relation to Plant Breeding. Indian Journal of. Genetics and Plant Breeding. 17: 318-28.

Panwar, L. L., 2005, Genetic variability, heritability and genetic advance for panicle characters in transplanted rice (Oryza sativa L.). Agric. Res. Stat. 3: 505508.

Ramanjaneyulu, A.V., Gouri Shankar, V., Neelima, T. L. and Shashibhusahn, D., 2014, Genetic analysis of rice (Oryza sativa 1.) genotypes under aerobic conditions on alfisols. SABRAO J. Breeding and Genetics, 46 (1): 99-111.

Samadhia, D. K., 2005, Genetic variability studies in Lasora (Cordiamyxa Roxb.). Indian J. of Pl. Genet. Res., 18(3): 236240.

Sedeek, S. M., Hammoud, S. A., Ammar, M. H. and Metwally, T. F., 2009, Genetic variability, heritability, genetic advance and cluster analysis for some physiological traits and grain yield and its components in rice (Oryza sativa L.). J. of Agri. Res. 35(3): 858-878.

Wright, S., 1935. The analysis of variance and correlations between relative with respect to deviations from an optimum. $J$. Genetics 30: 243-256.

\section{How to cite this article:}

Hosagoudar, G.N. and Basavaraj S. Kovi. 2018. Evaluation of Advanced Varietal Rice Genotypes for Leaf Blast Reaction, Genotypic Performance and Correlation Studies. Int.J.Curr.Microbiol.App.Sci. 7(04): 75-81. doi: https://doi.org/10.20546/ijcmas.2018.704.009 